\section{2. 耳性小腦真珠腫供覽}

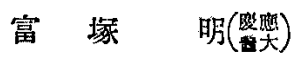

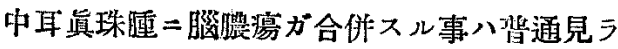

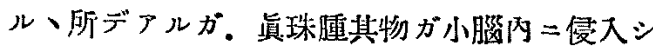

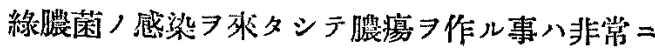

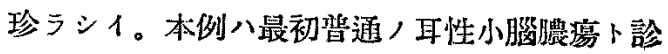
断シタノデアルガ. 死後剖检スルニ及ンデ如上

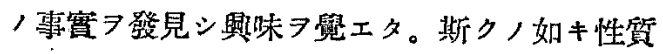

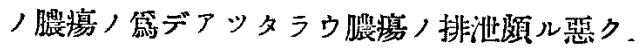

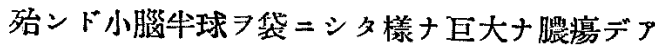
ツタニ拘ラズ. 造影劑使用 $=ヨ ル X$ 線竄真二八 僅二其一小部分シカ現ハレテ居ナ1。腰韵壁が 貪珠厘 =

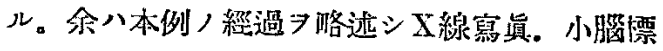

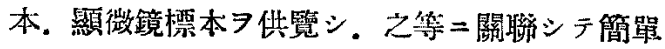

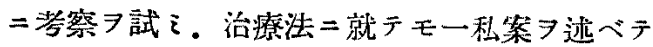
見タイ。

次 $=$ 臨牀的經過卜剖检所見卜／大略ヨ記傤シテ 㯰ク。

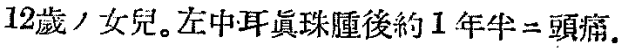
哑昍. 先側脚/運動失調 全身的ニハ身體八肥滿シ. 顐貌八無力呺態. 全 身, 箊肉弛緩シ均衡障碍著明ナリ。眠八雨側二

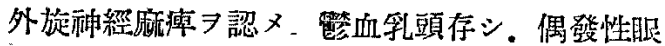
震八證明シ得ズ。局所的二八耳後二瘦狼性二治 癒セル手術創アリ耳鏡所見トシテハ鼓室二肉

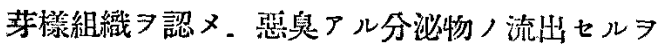
認よ。腰椎穿刺 結果腦雀䯣液㻺 $400 \mathrm{~mm}$ ナレ ト．細胞數，增加著明ナラズ。以上，所見ョリ

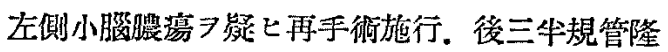

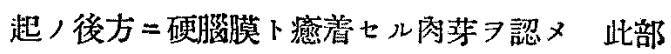

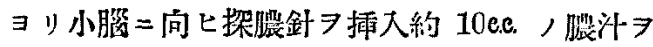
吸引ス。此部二卯開习加へ「ゴムドレイン」ヨ
插入ス。衍後一時全身狀態可良トナリシェ．矿

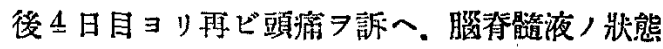
モ漱次惡化シ。術後 16 日目=鬼籍二入ル。 剖檢ニヨレバ蕒珠腫ノ發育ハ中耳 $ヨ$ り頭蓋骨質 ヨ破少䑏底二達シ。左側小腦牛球底部二於テ硬

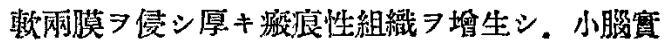
質 7 被七テ其上方八左側胋橋直下二迄澾七り。

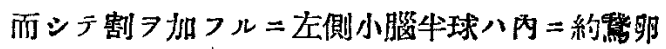

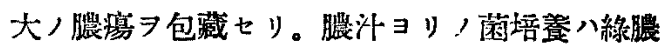
菌ヨ殆ンド純唔養ノ狀態二證明セリ。

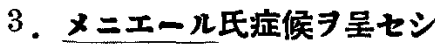

糨者ノ㯖器

山川强四郎(音婹)

$x=x ー ル$ 氏病八同症候解二於ケル病理變化 二就テハ中榀. 禩神經又八內耳二於ヶル出血。 充血若シク八貧血，內耳壓，六僬等卜稱七ラル ルモ資料僅少，篇义不明，點多シ。故阪大名策 教授緒方博士八生前林症二篗ラレ居り遗言二テ

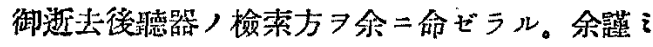
テえヨ检索シ其所見フ報告セントス。

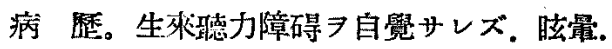

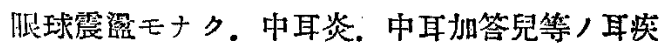
二䍜ラレタル事ナカリキ。逝去满 2 年前. 59 孫 , 時短如最初, 昡莗。惡心。嘔吐. 步行障碍 發生シ一夜ニシテ全快ス。6 日後。10日後再發。 12日後左側耳鳴加ハリ. 14 日後㯖力检查二テ左

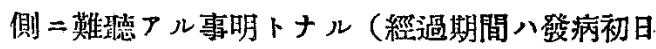
ヨリ記算セリ)。初回發作ニテハ患側凝视，際㛺

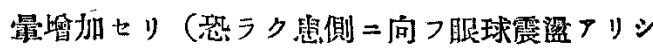
ナラン)。發病 23 日後余自身检查ス。鼓膜正常. 亶咽腔二モ病的所㫕ナシ。

爾來發作 7 繰返

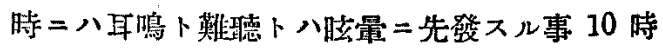
閒內外ナリキ。發作八原掌輕度ナリシニ，其持 
續ハ初回ノ一夜ヨリ次第二延長シ數日トナリ。 後ニハ步行障碍. 矓晕感數月，長キ二亘りテ存 シ所謂メニエール氏狀態トナレリ，又脑最及ビ 眠球震涩八時=右側㠜视，際二モ起ス事 リ。此間疆力检查 $\ni$ 行フ事 8 回. 成絔八時 $=\exists$ リ一定セズ. 即チ繁發作時ニモ異ナリ非發作㭙 ニ八輕快セり。多クハ左側が右側二比シ低音 階. 氣尊骨䢘及ビ高畐階共二强ク侵サレ居り。 右側八正常二近キ事多カリキ。例人バ發病後 1 多年ノ檢查ニテハA音文左側空氣傳䢟 58 秒。 右側 120 秒 (正常 130 秒). 骨傳導左側 70 秒. 右側 40 秒(正常 60 秒此呫例外ナリ). Fis ${ }^{4}$ 左側 15 秒．右側 28 秒 (正労 34 秒) ナリキ，眠球震 盗八發作初期 $=$ ノ 平性眠震 7 左側凝醍時, $i=$ 認メタリ。只稀二 右側凝祝時右側二向フ小水平眠震 7 見タリ。 以上ノ所見ヨリ考へル時八左側が重ク右側八極 メテ輕度二且ツ稀ニ侵サレ居リシモノナラン。 病理所見。死因八急性肺炎。

主ナル變化ハ1 ライスネル氏膜，伸展延長七 儿事。2.脈絡率中數多人結石狀物ノ存在。3.

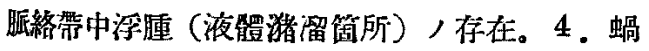

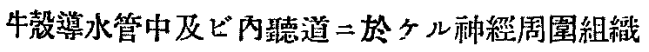
及ビ骨附近二於ヶル結石爿物ノ增加ナリ。 少シク詳細二述ブレバ螖牛㲄ニテ八蝶旋神經節 緗胞 =異常ナク退行變性及消失セル形跡ナク. 神綵瀻維モ亦骨管=充满ス郎千消失シ居ラズ。 骨輁及ビ脈絡帶中，血管=八血液充䨟スルモ血 管ノ著明ナ振㖘若シク八著シキ減少フ認メズ. 前庭階及ビ鼓室階清澄。蝸牛殻管內二八微量， 雲絮状物フルモ大䀦二清澄「フィブリン」及ど細 胞习認メズ。ライスネル氏膜八著シク伂展ス。

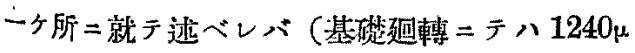

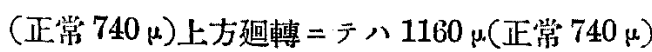
㱠ンド 2 倍近ク伸展ス。上方迴轉二テハ弓笽二 外淋巴腔二膨隆シ．下方廹䡜ニデハ一部膨隆シ 一部八波狀 7 呈ス（波彇习呈七ルハ「チェ口 イデン」包埋ノ際上牛規管フ開キタル第メ下方 迴轉內二於ヶル內淋巴ハ連合管习絁テー部流出 ヒル䉆ナラン)。コルチ氏膜ハ下方迴轉ニテハ螺 旋維, 延長線=在り扁平二近ク．上方廻轉二テ

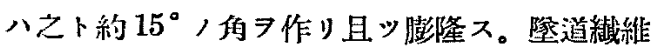
ニハ2 ケ所以上溜狀膨隆部アリ。脈絡帶八表面 凹凸著シク，厚不等．内部血管二八血液充滿 スルモ特別二摭張スルト八考へズ。脈絡帶中 人一部ニ八空洞形成フリ。空洞中ニ八網踈 7 呈 スル細胞存在スル故人工的 $=$ 涂離七ルモノ

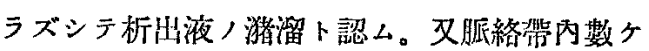
所二，首積不整球壯絬石狀物了リ此物八內皮細 胞㕱ノ物 ヨ以テ包マル。コルチ氏器，毛細胞核

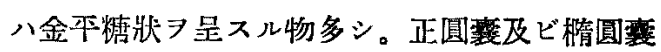

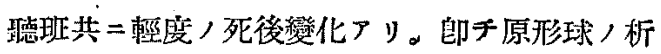
出. 感覺縕胞內腔洞形成アリ。細胞核，變化八 桱度ニシテ收縮及ビ「ピクノーゼ」無シ。备半 規管聽櫛モ輕度，死後變化アルノ $i$ 。螖牛殼導 水离清澄. 管腔二八網狀組織ナク．所々二結石 $ア ル モ$ 管腔徑二比シ著シク小（管腔徑 $700 \mu ，$ 所二結石直徑 $400 \mu$ 。 管腔遖徑 $400 \mu$ ，部 $=80$ $\mu$ （結石）ナリ。但シ絬石，數八左側 $=$ 遥二多

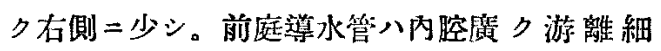
枹. 漂淡種タ「「コイド?」物質等 7 含么。

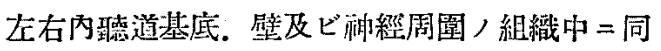
橙, 結石 $习$ 認又殊二左側 =多シ。

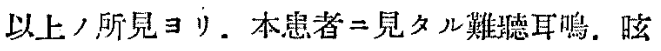

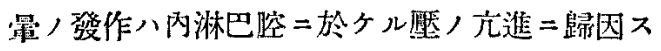
卜考フ。内耳，歷フ艺進セシムレバ聽力減弱ス 
ル事ハだレ一＼cjkstart检查ニテ想像シ得。盟昂進，原 因、脈絡帶 $ヨ$ リ分泌增㧈（洞形成モ之习說明 ス）=シテ更二其原因八脈絡帶中，結石形成。

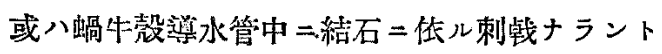
思惟ス。ウイットマーク先生ノ說/如ク結石二 依儿導水管八倣管八本例二テ八結石ガ微小ナル 點ヨリシテ考へラレズ。名螖牛殼導水管閉塞七 リトテライスネル氏膜ガ膨隆スルトハ考へラレ ズ。發作性ニ起リシ理由八，膽石惄石ノ如っ結

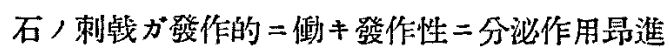
シ時日䌈過七バ. ライスネル氏膛／伸展外淋巴

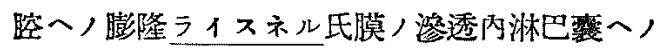
移動及ビ外淋巴液ガ笛キ莤脊䯣腔二移動スル事. 二依り埾ノ低下スル事=ヨリ證明シ得ベシ。脈 絡帶中二知ヶル結石ハ血管內=存スル如ク $=モ$ 見ユルガ. 椟血ヨ認メザル故持續性整血二低ル 分泌增加卜ハ考へラレズ。方先生ハプラウト敦 授ノ䙉器慓本 授ヨリ其寫貪 $习$ 鿓ヒ受ケタルニ，基礎趈轉=於 ケル神經繊維腫，外中上迵轉ニテハライスネル 氏膜が極度二仰展七ルラ認メ余ノ標本ト所見 一=ス。少數例 $ア$ 以テ判斷スル事八危險ナレ共. 内淋巴壓，聂進八本症卜關係アルモノト考フ。

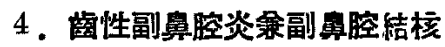

$$
\text { 森川謢 三(豦龺) }
$$

患者。26歳, 女中。

主 挀。惡臭鼻汁，頭痛，呟最。

芜族歷，㭃ニシテ天涯孤㯰．詳細不明。

既往整。幼時不䛨。10歲頃 3 リ耳漏. 眠疾.

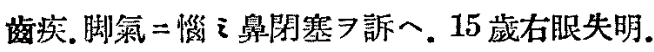
初潮 17 歲。来婚。

現症歷。1 月月前感冒踓患後多年，主訴疾悬 增惡シ鼻汁二血液 $フ$ 混ジ，擤舅，際得骨片，出
ズルアリ。頭痛甚ダシク．數日前右眼下部／腫 脹 日約 30 分/乘車中全々不快感二堪へス。

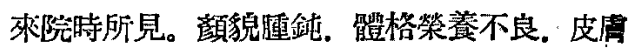
荅白. 體溫 $37.2^{\circ} \mathrm{O}$ ，呼吸 21 . 脈搏 95 . 律動尋

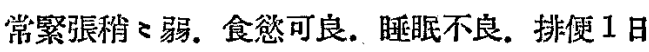

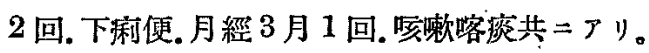

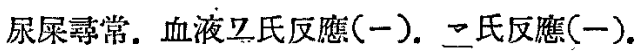
赤血球沈隆速度 10 分 -4.30 分一 7 ，1時間一 16 ( 赤血球 320 苟. 血色素 60(ザーリ). 白血球 6400 . 中性赀好性 70.5\%。分莱核 $68 \%$ ，桴狀 $2.5 \%$ 。 幼弱型 0 淋巴球 $22 \%$. 大單核 4\%.「エオジ ノ」 $2 \%$. 監基嗜好性 1.5\%。

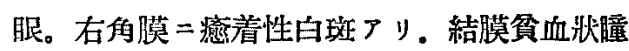
孔圆形. 射光反射. 右眠. 直射光線( - ). 間接光 線 $(+)$ 。近眠彗常。眠球突出右眼 $1.6 \mathrm{~mm}$. 左 眠 $1.4 \mathrm{~mm}$. 眠底右眠乳頭笭白，限界咬，左眼 尋常. 视力应眼 0.7 (1.2+世 0.75D) 右眼光覺箵 シ。而シテ眠科診斷ハ右眠蒸着性白斑球後神經 炎ナリ。

耳。兩耳鼓膜殆ンド全缺損. 小量䝢汒頯嵧. 双球菌. 連鋇狀球菌 7 見. 結核菌不詳. リンネ 氏試驗(一)。

䀢部。右肺上華落二水泡音 腹部. 四肢及ビ腱反射尋常。

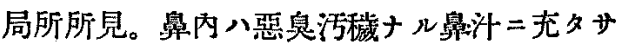
レ. 右下䦻介萎縮，中甲介不明．右中鼻道.下

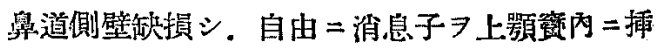
大シ得. 左鼻畉介八浮隀狀堙脹. 鼻中隔後部缺 損シ右壁八㦄憫狀トナル。

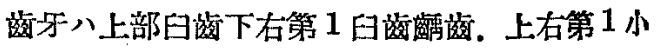

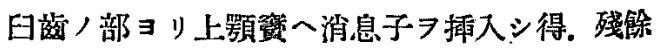

